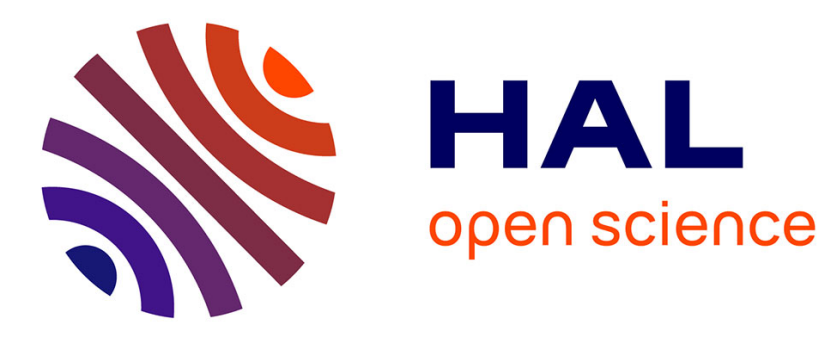

\title{
Candela photo-injector experimental results with a dispenser photocathode
}

C. Travier, B. Leblond, M. C. Bernard, J.N. Cayla, P. Thomas

\section{To cite this version:}

C. Travier, B. Leblond, M. C. Bernard, J.N. Cayla, P. Thomas. Candela photo-injector experimental results with a dispenser photocathode. 16th IEEE Particle Accelerator Conference (PAC 95) and International Conference on High-energy Accelerators (IUPAP), May 1995, Dallas, United States. pp.945-947, 10.1109/PAC.1995.505090 . in2p3-00022773

\section{HAL Id: in2p3-00022773 https://hal.in2p3.fr/in2p3-00022773}

Submitted on 5 May 2008

HAL is a multi-disciplinary open access archive for the deposit and dissemination of scientific research documents, whether they are published or not. The documents may come from teaching and research institutions in France or abroad, or from public or private research centers.
L'archive ouverte pluridisciplinaire HAL, est destinée au dépôt et à la diffusion de documents scientifiques de niveau recherche, publiés ou non, émanant des établissements d'enseignement et de recherche français ou étrangers, des laboratoires publics ou privés. 


\title{
CANDELA PHOTO-INJECTOR EXPERIMENTAL RESULTS WITH A DISPENSER PHOTOCATHODE ${ }^{*}$
}

\author{
C. Travier, B. Leblond, M. Bernard, J.N. Cayla, P. Thomas \\ Laboratoire de l'Acc Âlêtateur Linêtire, IN2P3-CNRS et UniversitêAde Paris-Sud \\ Bãł. 200, F-91405 Orsay
}

\author{
P. Georges

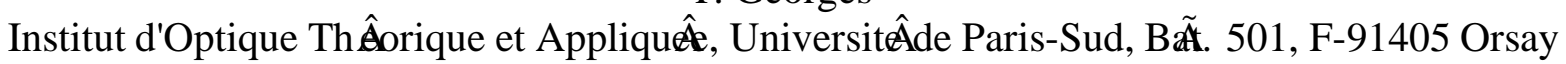

\begin{abstract}
The CANDELA photo-injector is a two cell S-band photoinjector. The dispenser photocathode is illuminated by a $500 \mathrm{fs}$ pulse from a frequency-tripled Ti:sapphire laser. In this paper we report charge measurements showing that the dispenser photocathode has a quantum ef®ciency as high as $10^{-3}$. This ef®ciency decreases with a lifetime of 12 hours, but can be recovered by heating the cathode during 5 minutes.
\end{abstract}

\section{INTRODUCTION}

The CANDELA photo-injector is an RF gun made of two decoupled $3 \mathrm{GHz}$ cells [1], [2], [3], [4]. The laser system used to illuminate the photocathode is a Ti:sapphire laser designed by the ${ }^{\circ}$ Institut d'Optique Th $\hat{e}$ orique et Appliquêt $\hat{\mathbf{e}}^{\circ}$ at Orsay [5]. CANDELA was @irst operated at the end of 1993 [6], with a copper photocathode. A maximum charge of $0.11 \mathrm{nC}$ was extracted corresponding to an effective quantum ef囚ciency of $5 \times 10^{-6}$. For laser -uences larger than $1 \mathrm{GW} / \mathrm{cm}^{2}$, very high charge can be produced (up to $35 \mathrm{nC}$ ), but in this case the pulse length is increased to $50 \mathrm{~ns}$ [7]. Since this ${ }^{\circ}$ intense emission ${ }^{\circ}$ process limits the maximum charge that can be obtained in the normal photoemission regime, we replaced the copper photocathode by a dispenser cathode that has a quantum ef $₫$ ciency more than 100 times better [8]. This paper presents the ${ }^{\circledR}$ rst results obtained with this cathode.

\section{CATHODE CONDITIONING}

The dispenser cathode (S-type) is normally used as a thermionic cathode in klystrons and electron guns for linear accelerators. The cathode we are using has a non-standard diameter of $9.2 \mathrm{~mm}$, and was fabricated for us by THOMSON TTE (Velizy), according to their standard fabrication procedure. The cathode consists of a porous tungsten matrix impregnated with barium calcium aluminate $\left(4 \mathrm{BaO}, 1 \mathrm{CaO}, 1 \mathrm{Al}_{2} \mathrm{O}_{3}\right)$. This $\mathrm{W}$ matrix is heated via a $囚 l a m e n t$. A thin molybdenum jacket is used to diminish heat losses (see ®gure 1).

The details of the cathode mounting in the gun cavity have already been reported [3]. The RF contact is made via a tungsten spring. In order to keep the required cathode heating power at a reasonable level, the part of the cavity in contact with the spring,

\footnotetext{
*Work supported by $\mathrm{IN}_{2} \mathrm{P}_{3}$ and ULTIMATECH under contract number 90N89/0018
}

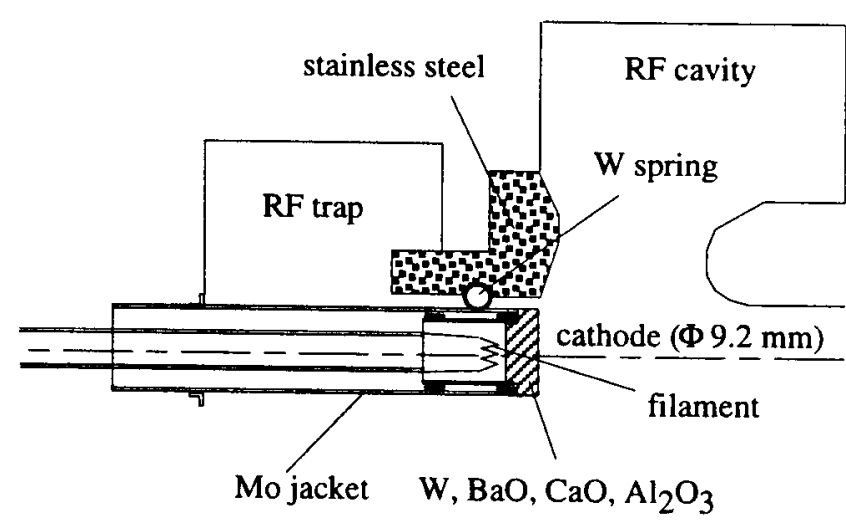

Figure. 1. Schematic of the cavity with dispenser cathode

is made of stainless steel which has a low thermal conductivity (see ${ }^{\circledR} \mathrm{g} .1$ ).

The cathode ${ }^{\circledR}$ rst needs to be conditioned to $1200^{\circ} \mathrm{C}$, in order to break the alumina and oxides molecules, so that free atoms of $\mathrm{Ba}$ and $\mathrm{Ca}$ can diffuse to the surface. During this conditioning, one has to maintain a vacuum pressure not higher than $10^{-6}$ mbar. But since the outgassing is quite signi ${ }^{\circledR}$ cant during this procedure, it can not be done inside the gun due to the limited pumping speed. However, since it was shown before that this cathode could sustain exposure to air without losses in photoemissive properties [8], the conditioning is made in a speci ${ }^{\circledR} \mathrm{c}$ vacuum chamber, with a pumping speed of $400 \mathrm{l} / \mathrm{s}$. After conditioning, which lasts for about 5 hours, the cathode is installed in the gun. This latter operation takes around one hour.

After the cathode installation, the gun is baked out at $150^{\circ} \mathrm{C}$ for three days. Then, the cathode should be slightly reconditioned. This is done by heating it to $1100^{\circ} \mathrm{C}$ for 5 minutes. This corresponds to a heating power of $56 \mathrm{~W}$. These two operations should be done each time the gun and cathode have to be exposed to air.

\section{LASER AND BEAMLINE}

The laser is a Ti:sapphire laser described in reference [5]. It produces one single pulse (at $12.5 \mathrm{~Hz}$ ), with an adjustable duration from $150 \mathrm{fs}$ to $15 \mathrm{ps}$, and a maximum energy of $200 \mu \mathrm{J}$ at $260 \mathrm{~nm}$.

The laser synchronization and modelocking starter systems have been improved since the description given in reference [5]. Originally, the starting of the modelocking and the synchroniza- 


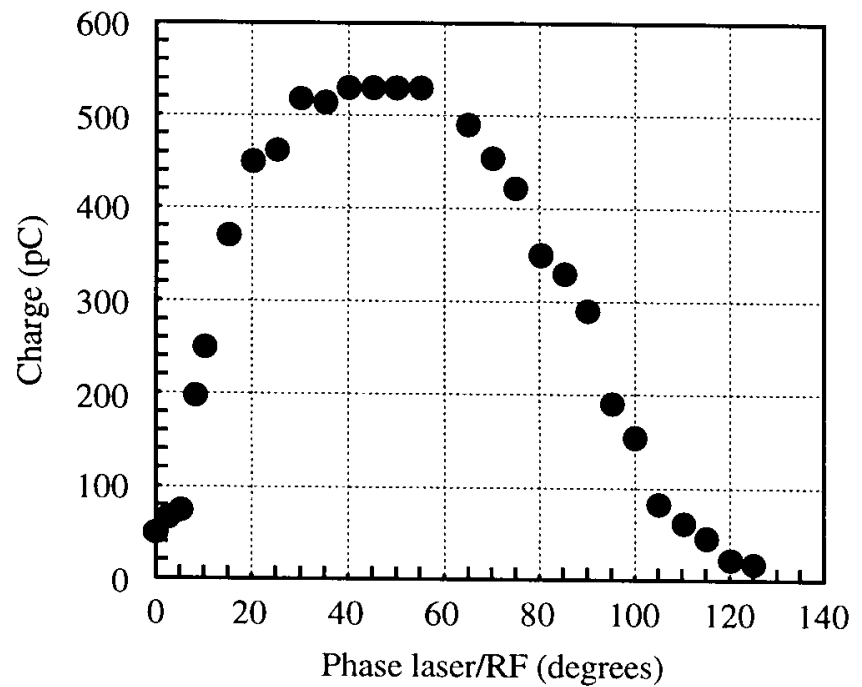

Figure. 2. Charge vs. laser/RF phase

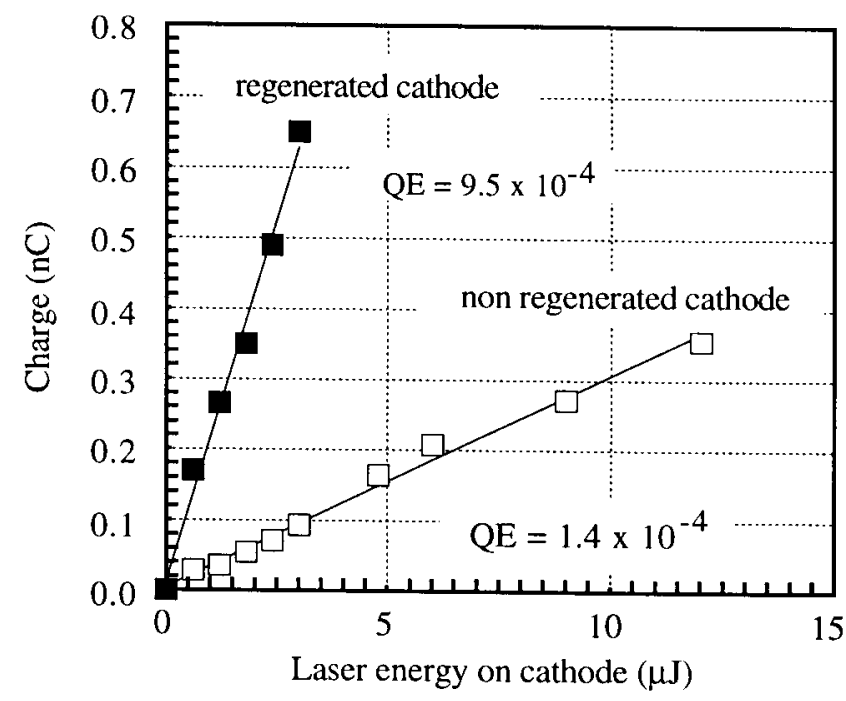

Figure. 3. Quantum ef®ciency of dispenser cathode tion of the laser frequency with the RF master oscillator were made via a single piezo-electric transducer on which one of the mirrors of the laser oscillator cavity was mounted. These operating conditions were not very comfortable, since very often we lost the modelocking operation while trying to lock the laser to the RF frequency. To improve this situation, we decoupled the two functions. The modelocking starter is now made with a pair of oscillating Brewster plates [9]. The synchronization is still achieved via a piezo-electric transducer and the slow thermal drifts are compensated by a translation stage driven by a DC motor. This new system proved very ef®cient and reliable.

The beamline including the beam diagnostics devices is described in reference [7]. At the time of measurements presented here, the ${ }^{\circledR}$ rst wall current monitor located right at the gun exit was not available. The charge measurements reported in the next sections were made with the coaxial Faraday cup situated about $1 \mathrm{~m}$ downstream of the gun, and an integrator. They were obtained in the following conditions:

- the laser pulse length is set to the sub-picosecond regime

- the laser illuminates the cathode with a 54.5 degrees angle with respect to normal incidence

- only the ${ }^{\circledR}$ rst cell of the gun is powered with $1.06 \mathrm{MW}$, which corresponds to a peak on axis ®eld of $68 \mathrm{MV} / \mathrm{m}$ and a cathode ${ }^{\circ}$ eld of $50 \mathrm{MV} / \mathrm{m}$

- the relative phase between laser and RF is chosen to optimize the extracted charge. The typical dependence of the charge with this phase is shown on ${ }^{\circledR}$ gure 2 .

\section{QUANTUM EFFICIENCY AND LIFETIME}

Figure 3 shows the measured charge as a function of the laser energy on cathode. The slope of these curves gives the effective quantum ef囚ciency $(\mathrm{QE})$ including the potential losses in the beam transport. Two different curves corresponding to two different situations are shown. The lower ef®ciency curve is obtained with the photocathode at room temperature after several hours spent in the gun at a residual static vacuum pressure better that $10^{-10}$ mbar (a few $10^{-9}$ with RF on). In these conditions the ef囚ciency is just slightly above $10^{-4}$. In order to improve the ef®ciency by almost one order of magnitude, it is necessary to regenerate the cathode prior to operation. This is done by heating it to around $700^{\circ} \mathrm{C}$, during $\circledR$ ve minutes (this corresponds to 25 $\mathrm{W}$ of heating power). After letting the cathode cool down during 15 minutes, it is ready to operate. In these conditions, the QE almost reaches $10^{-3}$, which is better than any pure metallic cathode $^{1}$. Due to the pollution caused by the residual gas, the $\mathrm{QE}$ then drops with time. If the lifetime is de ${ }^{\circledR}$ ned as usual as the time necessary to decrease the QE by a factor $1 / \mathrm{e}$, the cathode operated at cavity temperature $\left(31^{\circ} \mathrm{C}\right)$, has a lifetime of only two hours. However, the lifetime is improved drastically by slightly heating the cathode during operation. The temperature should of course stays below the thermoemission threshold. In our case we use $6 \mathrm{~W}$ of heating power. Under these conditions, the lifetime is increased to more than 12 hours. At any time one can recover the original $\mathrm{QE}$ by regenerating the cathode according to the procedure described above.

\section{SATURATION}

The charge that can be extracted from the photocathode is limited by space charge effects. When the charge increases, the self ®eld of the bunch can balance theaccelerating ®eld, so that no more charge can be extracted. Since the laser transverse pro®le is not uniform, but closer to Gaussian, the charge reaches the limit in the center of the cathode @rst. As explained by Hartman et al. [10], the charge can still be increased till the limit is reached also on the edge. See ${ }^{\circledR}$ gure 4 for the results corresponding to the dispenser cathode with and without regeneration.

During these experiments, we did not have any camera to monitor the laser transverse pro®le. However, by ${ }^{\circledR}$ tting the experimental data of ®gure 4 with the theoretical model of the saturation effect as described in reference [10], it is possible to infer the spot size. Figure 4 shows the result of this ${ }^{\circledR} t$ assuming a laser pro®le with a gaussian distribution truncated at $\pm 3 \sigma$.

\footnotetext{
${ }^{1}$ Magnesium for example has an ef®ciency of $5 \times 10^{-4}[11]$
} 


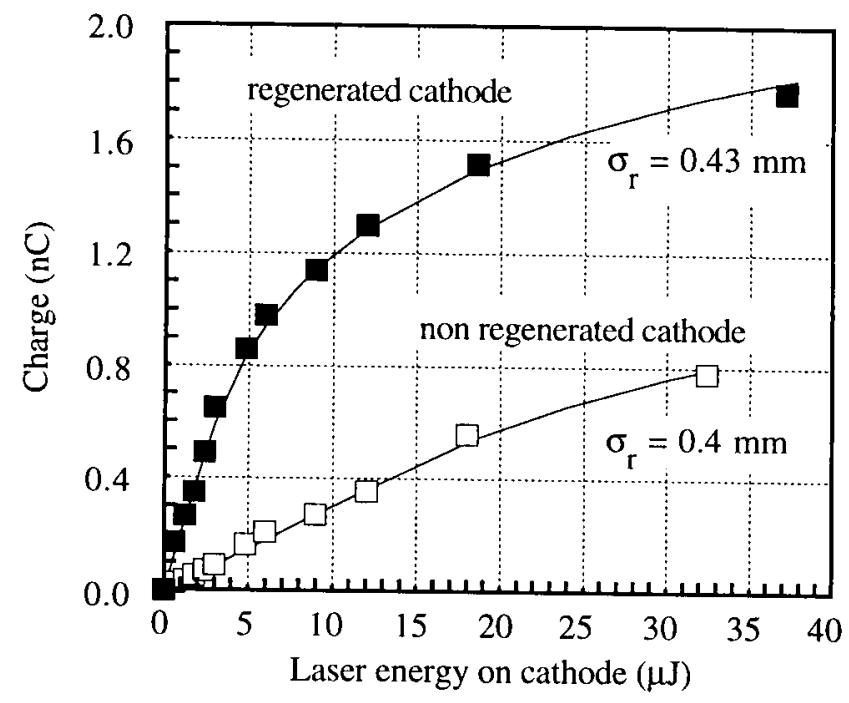

Figure. 4. Charge saturation

\section{FUTURE PROSPECTS}

In the near future, the other parameters of the beam will be measured, especially the pulse length and emittance. The pulse length will be measured by observing, with a streak camera (resolution $<2$ ps), the Cerenkov light produced by a $300 \mu \mathrm{m}$ thick sapphire. The emittance will be measured both with the three gradient method and with the ${ }^{\circ}$ pepper-pot ${ }^{\circ}$ method.

\section{CONCLUSION}

This paper has described the ${ }^{\circledR}$ rst use of a dispenser photocathode in a S-band RF gun. It is shown that this type of cathode when properly conditioned and operated, has a quantum ef®)iency of $0.1 \%$, which is better than that of pure metallic cathodes. The lifetime of this cathode is larger than 12 hours, and the original quantum ef®ciency can be recovered in 20 minutes, by heating. A total charge of $1.8 \mathrm{nC}$ was measured, only limited by saturation effects due to the relatively small spot size.

\section{ACKNOWLEDGEMENTS}

The design and construction of the CANDELA photo-injector has involved several people, who should be duly acknowledged. We also thank J.P. Chamberret (ENSTA/LOA) for the loan of the oscillating Brewster plate system. Finally, a special thanks for T. Garvey who carefully red this manuscript.

\section{References}

[1] C. Travier, J. Gao, Proc. European Particle Accelerator Conference, Nice, June 12-16, 1990, pp. 706-708.

[2] C. Travier, J. Gao, H. Liu, Proc. Linear Accelerator Conference, Albuquerque, September 10-14, 1990, pp. 602-604.

[3] J. Gao et al., Proc. European Particle Accelerator Conference, Berlin, March 24-28, 1992, pp. 1020-1022.

[4] C. Travier et al., Nucl. Instr. \& Meth. B89 (1994), pp. 27-32.

[5] P. Georges et al., Proc. Particle Accelerator Conference, Washington, May 17-20, 1993, pp. 3053-3054.
[6] C. Travier et al., Proc. European Particle Accelerator Conference, London, June 27 - July 1, 1994, pp. 1462-1464.

[7] C. Travier et al., Proc. Linear Accelerator Conference, Tsukuba, August 21-26, 1994.

[8] B. Leblond, Nucl. Instr. \& Meth. A317 (1992), pp. 365-372.

[9] Mira 900 data sheet, Coherent Inc.

[10] S.C. Hartman et al., NIM A340 (1994), pp. 219-230.

[11] X.J. Wang et al., NIM A356 (1995), pp. 159-166. 